\title{
Performance and morphology of intestinal mucosa of broilers fed mannan-oligosaccharides and enzymes
}

\author{
[Desempenho e morfologia da mucosa intestinal de frangos de corte alimentados com \\ mananoligossacarídeos e enzimas] \\ M.C. Oliveira ${ }^{1}$, E.A. Rodrigues ${ }^{2}$, R.H. Marques ${ }^{2}$, R.A. Gravena ${ }^{2}$, \\ G.C. Guandolini ${ }^{2}$, V.M.B. Moraes ${ }^{2}$ \\ ${ }^{1}$ Faculdade de Medicina Veterinária - FESURV \\ Caixa Postal 244 \\ 75901-970 - Rio Verde, GO \\ ${ }^{2}$ Faculdade de Ciências Agrárias e Veterinárias - UNESP - Jaboticabal, SP
}

\begin{abstract}
The performance and the morphology of intestinal mucosa of broilers fed mannan-oligosaccharides (MOS) and enzymes (E) from one to 21-day-old were evaluated using 750 one-day-old chicks, assigned to a $2 \times 2+1$ factorial design - two levels of MOS $(0$ and $0.1 \%)$, two levels of $\mathrm{E}(0$ and $0.05 \%)$ plus an antibiotic positive control diet - performing five treatments of five replications each one. MOS x E interaction was significant for both duodenal $(\mathrm{P}<0.002$ and $\mathrm{P}<0.002)$ and ileal $(\mathrm{P}<0.04$ and $\mathrm{P}<0.05)$ perimeters and heights of villi, being the values lower in the mucosa of birds fed non-supplemented diets. MOS based-diet determined an increase on perimeter of jejunal villi $(\mathrm{P}<0.05)$. Compared with antibiotic treatment group, villi perimeter $(\mathrm{P}<0.02)$ and height $(\mathrm{P}<0.005)$, and crypt depth $(\mathrm{P}<0.02)$ of duodenum of broiler fed MOS were higher. Broilers fed MOS and/or E did not perform better, but higher villi perimeter and height were observed in the intestinal mucosa of those birds.
\end{abstract}

Keywords: broiler, nutrition, enzymes, prebiotic

\section{RESUMO}

Avaliaram-se o desempenho e a morfologia da mucosa intestinal de frangos de corte alimentados com mananoligossacarídeos (MOS) e enzimas (E) até os 21 dias de idade. Utilizaram-se 750 pintainhos de um dia em delineamento experimental inteiramente ao acaso, em esquema fatorial $2 \times 2+1$ (dois níveis de MOS - 0 e $0,1 \%$, dois níveis de $E$ - 0 e 0,05\% e uma dieta controle positivo com antibióticos) totalizando cinco tratamentos com cinco repetições cada. A interação MOS x E foi significativa para o perímetro de altura de vilos no duodeno $(P<0,02$ e $P<0,02)$ e no íleo $(P<0,04$ e $P<0,05)$, sendo os valores menores observados na mucosa das aves alimentadas com dietas não-suplementadas. A dieta contendo MOS determinou aumento no perímetro dos vilos no jejuno $(P<0,05)$. Comparado com o grupo controle positivo, o perímetro $(P<0,02)$ e a altura $(P<0,005)$ dos vilos e a profundidade de cripta $(P<0,02)$ no duodeno das aves do tratamento com MOS foram maiores. As aves que consumiram dietas com MOS elou E não tiveram melhor desempenho, mas maiores perimetros e alturas de vilos foram observados na mucosa intestinal dessas aves.

Palavras-chave: frangos de corte, enzimas, nutrição, prebiótico

\section{INTRODUCTION}

Among substances quoted as prebiotic, the mannan-oligosaccharides (MOS) has emerged. They are fragments of cellular wall of Saccharomyces cerevisiae, containing in their structure mannose, glucose, and protein (Spring et al., 2000). They have been associated to better performance of broilers (Flemming et al., 2004). Although corn and soybean-based diets are considered to be of low viscosity, these feedstuffs have non-starch polysaccharides

Recebido em 31 de julho de 2007

Aceito em 17 de março de 2008

E-mail: cristina@fesurv.br 
(NSPs) in their structures (Kocher et al., 2003). Dietary exogenous enzymes diminish the antinutritional effects of NSPs while furnishing extra quantity of endogenous enzymes synthesized by the gastrointestinal tract (GIT) of the poultry. Improvement of body weight gain and feed conversion of 18-day-old broiler chickens were obtained with the use of dietary cellulase (Meng et al., 2005).

Feeding 0.1 to $0.5 \%$ of MOS to broilers, some authors registered deeper jejunal and ileal crypts (Iji et al., 2001) and augment of perimeter and height of duodenal villi (Loddi, 2003); however, the same amount of MOS furnished to turkeys resulted in smaller villi height as compared to groups fed antibiotics-based diets (Sims et al., 2004).

The use of exogenous enzymes that promote hydrolysis of NSPs can increase the height of villi and the proportion height-to-depth of the crypts, and lower the bacterial activity of the GIT as well (Mathlouthi et al., 2002a). Very high bacterial growth in the GIT can negatively interfere with the digestibility of both nitrogen and fat of the diet (Mathlouthi et al., 2002b).

This study aimed to evaluate the effects of the diet inclusion of MOS and enzymes (E) upon the performance and morphology of intestinal mucosa of broilers at 21 days of age.

\section{MATERIAL AND METHODS}

Seven hundred and fifty one-day-old Cobb chicks averaging $41.51 \pm 0.59 \mathrm{~g}$ were randomly assigned to a $2 \times 2+1$ factorial design - two levels of $\operatorname{MOS}^{1}(0$ and $0.1 \%)$ vs two levels of enzymes $^{1}(0$ and $0.05 \%)$ plus an antibiotic positive control diet - performing five treatments of five replicates each. Positive control diet contained colistin sulphate $(125 \mathrm{ppm})$ and virginiamycin $(10 \mathrm{ppm})$ as growth promoters, and salinomycin $(51 \mathrm{ppm})$ as anticoccidial. The diet with no MOS or enzymes was considered as negative control.

The enzyme phytase ${ }^{3}$ with minimal activity of $250 \mathrm{U} / \mathrm{g}$ was added to all diets, formulated to

${ }^{1}$ Bio-Mos and Allzyme Liquid Vegpro. Alltech do Brasil Agroindustrial Ltda. - Araucária, Brazil.

${ }^{3}$ Allzyme Phytase 2X. Alltech Inc. - Nicholasville, USA. have $0.38 \%$ of available phosphorus that was correspondent to $85 \%$ of the broiler chicken requirement on starter phase. Experimental mashed diets showed in the Table 1 were isonutritives and formulated to meet requirements proposed by Rostagno et al. (2000) for feeding broiler chickens until 21 days of age, except for metabolizable energy (ME) and crude protein (CP) that were $98 \%$ of the level recommended by the latter authors. Water and feed were provided ad libitum. Liquid enzyme, a blend of cellulase, protease, and $\alpha$-amylase was premixed in $500 \mathrm{~g}$ of soybean meal before inclusion to the diets.

At 21 days of age, body weight gain, feed intake, feed conversion, and liability of the broilers were evaluated. After $12 \mathrm{~h}$ of fasting, four birds per treatment were submitted to euthanasia, and two samples $(2 \mathrm{~cm}$ each one) were taken from the midpoint of the duodenum, from the midpoint between the point of entry of the bile duct and vitelline diverticulum (jejunum), and midway between Meckel's diverticulum and the ileocecal junction (ileum) from each broiler, one for light and other for scanning electron microscopy techniques.

For light microscopy, the segments were opened and rinsed with phosphate buffer $(0.1 \mathrm{M}, \mathrm{pH} 7.4)$ and fixed in Bouin's solution for 24 hours. Afterward, they were dehydrated in a graded series of ethanol, diaphanized in xylene and paraffin embedded. Cross sections of the intestine were made at $5 \mu \mathrm{m}$ and they were stained with hematoxylin and eosin. Forty readings per sample for villi perimeter and height, and crypt depth were done. The counting of the number of goblet cells was done in an area of $1 \mathrm{~mm}$ square.

For scanning electron microscopy, the samples of each intestinal segment were fixed in glutaraldeyde (3\%) for 48 hours and then rinsed with phosphate buffer $(0.1 \mathrm{M}, \mathrm{pH} 7.4)$. The samples were post-fixed in $2 \%$ osmium tetra oxide for two hours and rinsed again with the same buffer solution. Afterward, they were dehydrated in a graded series of ethanol and dried in $\mathrm{CO}_{2}$ critical point dryer. The dried samples were metalized with gold/palladium and examined with a Jeol-JSM 5410 scanning electron microscope (operated at $15 \mathrm{kV}$ ) from three areas ( $1 \mathrm{~mm}$ square each one) of each sample for the villi density. 
Table 1. Ingredient and chemical composition of experimental diets containing mannan oligosacharides (MOS) or enzymes (E) fed to broiler chickens from one to 21-day-old

\begin{tabular}{|c|c|c|c|c|c|}
\hline \multirow[b]{2}{*}{ Ingredient } & \multicolumn{5}{|c|}{ Treatment } \\
\hline & $\begin{array}{c}\text { Positive } \\
\text { control }\end{array}$ & $\begin{array}{l}\text { Negative } \\
\text { control }\end{array}$ & $\mathrm{E}$ & MOS & $\mathrm{MOS}+\mathrm{E}$ \\
\hline Corn & 59.74 & 59.74 & 59.74 & 59.74 & 59.74 \\
\hline Soybean meal & 34.34 & 34.34 & 34.34 & 34.34 & 34.34 \\
\hline Soybean oil & 1.58 & 1.58 & 1.58 & 1.58 & 1.58 \\
\hline Dicalcium phosphate & 1.45 & 1.45 & 1.45 & 1.45 & 1.45 \\
\hline Limestone & 1.22 & 1.22 & 1.22 & 1.22 & 1.22 \\
\hline DL-Metionine 99\% & 0.04 & 0.04 & 0.04 & 0.04 & 0.04 \\
\hline L-Lysine $78.8 \%$ & 0.20 & 0.20 & 0.20 & 0.20 & 0.20 \\
\hline Salt & 0.45 & 0.45 & 0.45 & 0.45 & 0.45 \\
\hline Phytase & 0.01 & 0.01 & 0.01 & 0.01 & 0.01 \\
\hline $\operatorname{MOS}^{1}$ & - & - & - & 0.10 & 0.10 \\
\hline Enzymes $^{1}$ & - & - & 0.05 & - & 0.05 \\
\hline Caulim & 0.15 & 0.15 & 0.10 & 0.05 & - \\
\hline Antioxidant & 0.02 & 0.02 & 0.02 & 0.02 & 0.02 \\
\hline \multirow[t]{2}{*}{ Mineral and vitamin premix } & $0.80^{2}$ & $0.80^{3}$ & $0.80^{3}$ & $0.80^{3}$ & $0.80^{3}$ \\
\hline & \multicolumn{5}{|c|}{ Calculated nutrients } \\
\hline Crude protein $(\%)$ & 21.00 & 21.00 & 21.00 & 21.00 & 21.00 \\
\hline $\mathrm{ME}(\mathrm{Kcal} / \mathrm{kg})$ & 2,940 & 2,940 & 2,940 & 2,940 & 2,940 \\
\hline Calcium $(\%)$ & 0.96 & 0.96 & 0.96 & 0.96 & 0.96 \\
\hline Available phosphorus (\%) & 0.38 & 0.38 & 0.38 & 0.38 & 0.38 \\
\hline Lysine $(\%)$ & 1.26 & 1.26 & 1.26 & 1.26 & 1.26 \\
\hline Methionine (\%) & 0.49 & 0.49 & 0.49 & 0.49 & 0.49 \\
\hline
\end{tabular}

${ }^{\mathrm{T}}$ Per kg: phosphorilated mannan oligosaccharides $30 \%$.

${ }^{2}$ Per kg of premix: $1,500,000$ UI vit. A; 285,000 UI vit. $D_{3}$, $1350 \mathrm{mg}$ vit.E, $230 \mathrm{mg}$ vit. $\mathrm{K}_{3}, 115 \mathrm{mg}$ vit. $\mathrm{B}_{1}, 1150 \mathrm{mg}$ vit. $\mathrm{B}_{2}$, $2,000 \mathrm{mcg}$ vit. $\mathrm{B}_{12}, 4,800 \mathrm{mg}$ nicotinic acid, $1,240 \mathrm{mg}$ pantothenic acid, $230 \mathrm{mg}$ pyridoxine, $12 \mathrm{mg}$ biotin, $115 \mathrm{mg}$ folic acid, 85g choline, 170g methionine, 6,300mg Fe, 9,400mg Cu, 9,400mg Mn, 7,819mg Zn, 160mg I, 23mg Se, 20g antioxidant, $5.4 \mathrm{~g}$ growth promoter, $6.4 \mathrm{~g}$ anticoccidial.

${ }^{3}$ The same as in 2 but with no growth promoter and anticoccidial.

The data obtained of MOS x enzyme factorial were submitted to the two-way ANOVA test and the means were compared by the Tukey test. The Dunnett test was used to check significant differences among the means of positive control treatment and MOS x enzymes factorial.

\section{RESULTS AND DISCUSSION}

Performance (data not shown) was not influenced by treatments $(\mathrm{P}>0.05)$. Average body weight $(862 \mathrm{~g})$, weight gain $(821 \mathrm{~g})$, feed intake $(1,185 \mathrm{~g})$, feed conversion (1.44) and liability $(98.80 \%)$ were comparable to those obtained for Cobb broilers at 21 days of age.

Although MOS and enzymes are considered promoters of better digestibility of nutrient and could improve performance of broilers as consequence, the use of these additives, either isolated or associated, did not determine any beneficial effects in this study; but similar performance results of broiler chickens compared to antibiotic use were achieved. It is possible that the non-effective action of both MOS and enzymes reflected the good housing conditions provided to the birds. On the other hand, reduced ME and CP levels of diet without enzymes did not sufficiently depress the performance of chickens (data not shown).

Hooge et al. (2003) and Flemming et al. (2004) obtained similar results of non-improvement on performance of 21-day-old broiler chickens fed $0.01 \%$ to $0.10 \%$ of MOS. Also, Iji et al. (2003) and Pinheiro et al. (2004) did not find any difference upon the performance of chickens fed cellulase, protease, and $\alpha$-amylase supplemented diets. Kirkpinar et al. (2004) tested prebiotic and $\mathrm{E}$ (protease, amylase, cellulase, xylanase, lipase, 
phytase, and $\beta$-glucanase), and no increase on broiler performance was achieved.

A MOS $x$ E interaction was observed for perimeter $(\mathrm{P}<0.002)$ and height $(\mathrm{P}<0.002)$ of duodenum villi (Table 2) that were larger compared to those of negative-control chickens. In jejunal segment (Table 3), addition of MOS to the diet increased $(\mathrm{P}<0.05)$ the perimeter of the villi. On the other hand, perimeter $(\mathrm{P}<0.04)$ and height $(\mathrm{P}<0.05)$ of ileum (Table 4$)$ villi from chickens fed non-additive diets were both smaller. Compared to chickens fed antibiotictreated diet, duodenal villi from birds of MOS group had larger perimeter $(\mathrm{P}<0.02)$, larger height $(\mathrm{P}<0.005)$, and deeper crypts $(\mathrm{P}<0.02)$.

Probably, the high proliferation of all types of bacteria in duodenum and ileum of broiler chicken fed diets without antibiotic, MOS and/or E damaged the intestinal mucosa. This effect could justify the lower villi perimeter and height in duodenum and ileum segments obtained from non-supplemented birds, as suggested by Juskiewicz et al. (2004) and Santos Jr. et al. (2004).

On the other hand, the increased size of the villi and the deeper crypts observed in the gut mucosa of broiler chickens fed MOS, as compared to those fed antibiotic, seems to be due to the limited bacterial capacity of proliferation and colonization determined by the use of antibiotic. The reduction of crypt depth coupled with lower villi height and perimeter are indicative that the epithelial turnover diminished as consequence of the suppression of beneficial bacteria in the gut, as Lactobacillus and bifidobacteria. Such effect diminishes the production of short chain fatty acids (SCFA) and increases the intestinal $\mathrm{pH}$, supporting the development of pathogenic bacteria (Edens et al., 1997) that damage the mucosa of the intestine (Ferket, 2004).

Table 2. Perimeter (PV) and height (HV) of villi, crypt depth (CD), and goblet cell (GCD), and villi densities (VD) of duodenum of 21-day-old broilers fed according to dietary treatments

\begin{tabular}{|c|c|c|c|c|c|c|c|}
\hline $\begin{array}{l}\text { Positive } \\
\text { control }^{1}\end{array}$ & MOS & Enzymes & $\begin{array}{c}\text { PV } \\
(\mu \mathrm{m})\end{array}$ & $\begin{array}{l}\mathrm{HV} \\
(\mu \mathrm{m})\end{array}$ & $\begin{array}{l}\text { CD } \\
(\mu \mathrm{m})\end{array}$ & $\mathrm{GCD} / \mathrm{mm}^{2}$ & $\mathrm{VD} / \mathrm{mm}^{2}$ \\
\hline+ & - & - & 2,361 & 1,161 & 126 & 736 & 22.92 \\
\hline - & - & - & $2,332 b$ & $1,167 b$ & 155 & 770 & 18.70 \\
\hline- & - & + & $2,807 \mathrm{a}$ & $1,408 \mathrm{a}$ & 164 & 806 & 15.93 \\
\hline- & + & - & $2,972 \mathrm{a}^{*}$ & $1,513 \mathrm{a}^{*}$ & $189 *$ & 837 & 17.68 \\
\hline- & + & + & $2,759 \mathrm{a}$ & $1,391 \mathrm{a}$ & 167 & 591 & 21.81 \\
\hline & - & & 2,570 & 1,288 & 159 & 788 & 17.32 \\
\hline & + & & 2,865 & 1,452 & 178 & 714 & 19.75 \\
\hline & & - & 2,652 & 1,340 & 172 & 803 & 18.19 \\
\hline & & + & 2,783 & 1,399 & 165 & 699 & 18.87 \\
\hline & & & \multicolumn{5}{|c|}{ Probability $(\mathrm{P}<)$} \\
\hline \multicolumn{3}{|c|}{ Positive control $v s$ factorial } & 0.02 & 0.006 & $0.02^{\circ}$ & NS & NS \\
\hline \multicolumn{3}{|c|}{ MOS } & 0.05 & 0.003 & NS & NS & NS \\
\hline \multicolumn{3}{|c|}{$\mathrm{E}$} & NS & NS & NS & NS & NS \\
\hline \multicolumn{3}{|l|}{ MOS vs E } & 0.002 & 0.002 & NS & NS & NS \\
\hline \multicolumn{3}{|l|}{ SE } & 78.86 & 41.52 & 6.50 & 58.70 & 1.03 \\
\hline
\end{tabular}

$+=$ with; - = without. NS = non significant.

Means within the same column followed by distinct letters differ by Tukey test $(\mathrm{P}<0.05)$.

* Different from positive control by Dunnett test at $\mathrm{P}<0.05$.

${ }^{1}$ Growth promoter (colistin sulphate, $125 \mathrm{ppm}$ and virginiamycin, 10ppm) and anticoccidial (salinomycin, 51ppm). 
Table 3. Perimeter (PV) and height (HV) of villi, crypt depth (CD), and goblet cell (GCD), and villi densities (VD) of jejunum of 21-day-old broilers fed according to dietary treatments

\begin{tabular}{|c|c|c|c|c|c|c|c|}
\hline $\begin{array}{l}\text { Positive } \\
\text { control }^{1}\end{array}$ & MOS & Enzymes & $\begin{array}{c}\text { PV } \\
(\mu \mathrm{m})\end{array}$ & $\begin{array}{c}\mathrm{HV} \\
(\mu \mathrm{m})\end{array}$ & $\begin{array}{c}\text { CD } \\
(\mu \mathrm{m})\end{array}$ & $\mathrm{GCD} / \mathrm{mm}^{2}$ & $\mathrm{VD} / \mathrm{mm}^{2}$ \\
\hline+ & - & - & 1,734 & 852 & 126 & 1,145 & 26.97 \\
\hline- & - & - & 1,443 & 692 & 134 & 902 & 26.33 \\
\hline - & - & + & 1,750 & 894 & 123 & 1,116 & 24.71 \\
\hline - & + & - & 1,844 & 914 & 137 & 1,291 & 23.95 \\
\hline \multirow[t]{6}{*}{ - } & + & + & 1,809 & 890 & 147 & 1,369 & 25.65 \\
\hline & - & & $1,596 \mathrm{~b}$ & 793 & 128 & 1,009 & 25.52 \\
\hline & + & & $1,827 \mathrm{a}$ & 902 & 142 & 1,330 & 24.80 \\
\hline & & - & 1,644 & 803 & 135 & 1,097 & 25.14 \\
\hline & & + & 1,780 & 892 & 135 & 1,242 & 25.18 \\
\hline & & & \multicolumn{5}{|c|}{ Probability $(\mathrm{P}<)$} \\
\hline \multicolumn{3}{|c|}{ Positive control $v s$ factorial } & NS & NS & NS & NS & NS \\
\hline \multicolumn{3}{|c|}{ MOS } & 0.05 & NS & NS & NS & NS \\
\hline \multicolumn{3}{|l|}{ E } & NS & NS & NS & NS & NS \\
\hline \multicolumn{3}{|l|}{$\operatorname{MOS} v s \mathrm{E}$} & NS & NS & NS & NS & NS \\
\hline \multicolumn{3}{|l|}{ SE } & 60.50 & 33.70 & 6.40 & 97.33 & 0.55 \\
\hline
\end{tabular}

$+=$ with; - = without. $\mathrm{NS}=$ non significant.

Means within the same column followed by distinct letters differ by Tukey test $(\mathrm{P}<0.05)$.

${ }^{1}$ Growth promoter (colistin sulphate, $125 \mathrm{ppm}$ and virginiamycin, 10ppm) and anticoccidial (salinomycin, 51ppm).

Table 4. Villi perimeter (PV) and height (HV), crypt depth (CD), goblet cell (GCD), and villi densities (VD) of ileum of 21-day-old broilers fed according to dietary treatments

\begin{tabular}{|c|c|c|c|c|c|c|c|}
\hline $\begin{array}{l}\text { Positive } \\
\text { control }^{1}\end{array}$ & MOS & Enzymes & $\begin{array}{c}\text { PV } \\
(\mu \mathrm{m})\end{array}$ & $\begin{array}{c}\text { HV } \\
(\mu \mathrm{m})\end{array}$ & $\begin{array}{c}\text { CD } \\
(\mu \mathrm{m})\end{array}$ & $\mathrm{GCD} / \mathrm{mm}^{2}$ & $\mathrm{VD} / \mathrm{mm}^{2}$ \\
\hline+ & - & - & 1,475 & 668 & 116 & 1,183 & 35.97 \\
\hline - & - & - & $1,211 \mathrm{~b}$ & $584 \mathrm{~b}$ & 113 & 1,212 & 35.19 \\
\hline - & - & + & $1436 \mathrm{a}$ & $699 a$ & 120 & 1133 & 36.30 \\
\hline- & + & - & $1,392 \mathrm{ab}$ & $679 \mathrm{ab}$ & 120 & 982 & 36.45 \\
\hline \multirow[t]{6}{*}{-} & + & + & $1,310 \mathrm{ab}$ & $657 \mathrm{ab}$ & 106 & 1,251 & 33.04 \\
\hline & - & & 1,323 & 641 & 116 & 1,172 & 35.74 \\
\hline & + & & 1,351 & 668 & 113 & 1,116 & 34.74 \\
\hline & & - & 1,301 & 632 & 116 & 1,097 & 35.82 \\
\hline & & + & 1,373 & 678 & 113 & 1,192 & 34.67 \\
\hline & & & \multicolumn{5}{|c|}{ Probability $(\mathrm{P}<)$} \\
\hline \multicolumn{3}{|c|}{ Positive control $v s$ factorial } & NS & NS & NS & NS & NS \\
\hline \multicolumn{3}{|c|}{ MOS } & NS & NS & NS & NS & NS \\
\hline \multicolumn{3}{|l|}{$\mathrm{E}$} & NS & NS & NS & NS & NS \\
\hline \multicolumn{3}{|l|}{$\operatorname{MOS} v s \mathrm{E}$} & 0.04 & 0.05 & NS & NS & NS \\
\hline \multicolumn{3}{|l|}{ SE } & 39.06 & 18.90 & 4.95 & 110.86 & 1.14 \\
\hline
\end{tabular}

$+=$ with; - = without.

Means within the same column followed by distinct letters differ by Tukey test $(\mathrm{P}<0.05)$.

${ }^{1}$ Growth promoter (colistin sulphate. $125 \mathrm{ppm}$ and virginiamycin, 10ppm) and anticoccidial (salinomycin, 51ppm). 
In the jejunum, the inclusion of MOS to broiler diet increased villi perimeter probably enlarging the nutritive absorptive area. The stimulatory effects of MOS may be attributed to the production of SCFA after fermentation of digesta in the distal intestine. It was suggested that some SCFA induce cell proliferation of the intestinal mucosa (Lan, 2004).

It appears that the enzymes-based diets caused a higher effect upon the perimeter area and villi height of ileal mucosa than the use of MOS. This fact possibly occurred because the inclusion of the enzymes to the diet quantitatively lowered the available substrate to the bacteria growth, usually high in the lower segment of the small intestine. Besides, an increased retention time of the digesta in the gut could determine a higher hydrolysis by endogenous enzymes. According to Camiruaga et al. (2001), even non-viscous NSP can diminish the retention time of intestinal contents and impair the action of the enzymes present in the gut.

The increase of villi height and superficial area of birds subject to rich viscous cereal, protease, $\alpha$-amylase, and xylanase or $\beta$-glucanase diets was supposed to be a consequence of the lower concentration of intestinal bacteria (Gilbert et al., 2001; Mathlouthi et al., 2002a). Loddi (2003) and Sims et al. (2004) also observed higher height and perimeter of duodenal villi determined by the inclusion of MOS to broiler diet.

\section{CONCLUSIONS}

The present study showed that the use of MOS and/or E to diets of one to 21-day-old broilers did not improve their productive performance, despite the fact that higher perimeter and height of villi were observed in duodenum and ileum, increasing the absorption surface of these intestinal segments.

\section{ACKNOWLEDGMENTS}

This research was supported by Fundação de Apoio à Pesquisa do Estado de São Paulo (FAPESP), Alltech do Brasil Agroindustrial Ltda, and Fundação para o Desenvolvimento da UNESP (FUNDUNESP).

\section{REFERENCES}

CAMIRUAGA, M.; GARCIA, F.; ELERA, R. et al. Productive response of broiler chickens to exogenous enzyme combinations added to diets based on corn or triticale. Cienc. Invest. Agr., v.28, p.23-36, 2001.

EDENS, F.W.; PARKHURST, C.R.; CASAS, I.A. et al. Principles of ex ovo competitive exclusion and in ovo administration of Lactobacillus reuteri. Poult. Sci., v.76, p.179196, 1997.

FERKET, P.R. Alternatives to antibiotics in poultry production: responses, practical experience and recommendations. In: LYONS, T.P.; JACQUES, K.A. (Eds). ALLTECH'S ANNUAL SYMPOSIUM ON BIOTECHNOLOGY IN THE FEED INDUSTRY, 20., 2004, Nottinhgam. Proceedings... Nottingham, UK: Nottingham University, 2004. p.54-67.

FLEMMING, J.S.; FREITAS, J.R.S.; FONTOURA, $P$. et al. Use of mannanoligosaccharides in broiler feeding. Braz. J. Poult. Sci., v.6, p.159-161, 2004.

GILBERT, C.; ACAMOVIC, T.; BEDFORD, M.R. The effects of lupin inclusion with or without enzyme supplementation on the morphology of the posterior gastrointestinal tract. Br. Poult. Sci., v. 42, suppl.1, p.S90-S91, 2001.

HOOGE, D.M.; SIMS, M.D.; SEFTON, A.E. et al. Effect of dietary mannan oligosaccharide, with or without bacitracin or virginiamycin, on live performance of broiler chickens at relatively high stocking density on new litter. J. Appl. Poult. Res., v.12, p.461-467, 2003.

IJI, P.A.; KHUMALO, K.; SLIPPERS, S. Et al. Intestinal function and body growth of broiler chickens on diets based on maize dried at different temperatures and supplemented with a microbial enzyme. Reprod. Nutr. Dev., v.43, p.77-90, 2003.

IJI, P.A.; SAKI, A.A.; TIVEY, D.R. Intestinal development and body growth of broiler chicks on diets supplemented with non-starch polysaccharides. Anim. Feed Sci. Tech., v.89, p.175-188, 2001. 


\section{Oliveira et al.}

JUSKIEWICZ, J.; ZDUNCZYK, Z.; JANKOWSKI, J. Selected parameters of gastrointestinal tract metabolism of turkeys fed diets with flavomycin and different inulin content. World Poult. Sci. J., v.60, p.177-185, 2004.

KIRKPINAR, F.; AÇIKGÖZ, Z.; BOZKURT, $M$. et al. Effects of inclusion of poultry byproduct meal and enzyme-prebiotic supplementation in grower diets on performance and feed digestibility of broilers. Br. Poult. Sci., v.45, p.273-279, 2004.

KOCHER, A.; CHOCT, M.; ROSS, G. et al. Effects of enzyme combinations on apparent metabolizable energy of corn-soybean mealbased diets in broilers. J. Appl. Poult. Res., v.2, p.275-283, 2003.

LAN, Y. Gastrointestinal health benefits of soy water-soluble carbohydrates in young broiler chickens, 2004. 265f. Tese - Wageningen University, Wageningen.

MATHLOUTHI, N.; LALLÈS, J.P.; LEPERCQ, $P$. et al. Xylanase and $\beta$-glucanse supplementation improve conjugated bile acid fraction in intestinal contents and increase villi size of small intestine wall in broiler chickens fed a rye-based diet. J. Anim. Sci., v.80, p.27732779, 2002a.

MATHLOUTHI, N.; MALLET, S.; SAULNIER, L. et al. Effects of xylanase and $\beta$-glucanase addition on performance, nutrient digestibility, and physico-chemical conditions in the small intestine contents and caecal microflora of broiler chickens fed a wheat and barley-based diet. Anim. Res., v.51, p.395-406, 2002 b.

MENG, X.; SLOMINSKI, B.A.; NYACHOTI, C.M. et al. Degradation of cell wall polysacchardies by combinations of carbohydrase enzymes and their effect on nutrient utilization and broiler chicken performance. Poult. Sci., v.84, p.37-47, 2005.

PINHEIRO, D.F.; CRUZ, V.C.; SARTORI, J.R. et al. Effect of early feed restriction and enzyme supplementation on digestive enzyme activities in broilers. Poult. Sci., v.83, p.1544-1550, 2004.

ROSTAGNO, H.S.; ALBINO, L.F.T.; DONZELE, J.L. et al. Tabelas brasileiras para aves e suínos. Composição de alimentos $\mathrm{e}$ exigências nutricionais. Viçosa: Imprensa Universitária, 2000. 141p.

SANTOS Jr., A.A.; FERKET, P.R.; GRIMES, J.L. et al. Dietary pentosanase supplementation of diets containing different qualities of wheat on growth performance and metabolizable energy of turkey poults. Int. J. Poult. Sci., v.3, p.33-45, 2004.

SIMS, M.D.; DAWSON, K.A.; NEWMAN, K.E. et al. Effects of dietary mannan oligosaccharide, bacitracin methylene disalicylate, or both on the live performance and intestinal microbiology of turkeys. Poult. Sci., v.83, p.1148-1154, 2004.

SPRING, P.; WENK, C.; DAWSON, K.A. et al. The effects of dietary mannanoligosaccharides on cecal parameters and the concentrations of enteric bacteria in the ceca of Salmonellachallenged broiler chicks. Poult. Sci., v.79, p.205-211, 2000. 